\title{
Production of Hydrogen from Industrial Metal Waste
}

\author{
Sohair A. Sayed Ahmed, Reham M.M. Aboelenin, Ghada \\ M. Mohamed and M.M. Selim ${ }^{\#}$ \\ Physical Chemistry Dept., National Research Centre, NRC, 33 \\ Elbohouth St.- Dokki- Giza - Egypt - P.O. 12622 Egypt.
}

\begin{abstract}
7 HE production of hydrogen was obtained by catalytic reaction of aluminium with water. The reaction produces a large amount of heat and hydrogen gas. The presence of the catalyst is necessary because the reaction of the metal with water does not occur due to presence of a very thin passivation layer, $\mathrm{Al}_{2} \mathrm{O}_{3}$. In our case $\mathrm{NaOH}$, iodine and sodium chloride were selected to activate the aluminium surface, i.e. to remove the passive layer and allow the reaction to proceed. The aluminium used in the reaction comprises aluminium foil, electrical wire, beverage cans and other similar aluminium waste.
\end{abstract}

Keywords : Hydrogen generation, Aluminium metal scrap and Foil.

Due to the depletion of fossil fuels, especially oil and natural gas, and the concern over carbon dioxide $\left(\mathrm{CO}_{2}\right)$ emissions, there is an urgent need for sustainable and clean fuel substitutes for our future energy supply. Hydrogen has been proven to be a promising alternative fuel source because of its high heating value and regeneration capability. In addition, hydrogen has also been found to be the best fuel for fuel cells. On-board hydrogen production has received a lot of attention because it can generate/fuel the hydrogen where/when it is needed.

Several investigations about new energy sources have been carried out during the last decades. Concerns about a possible depletion of petroleum, coal and gas, as well as new methods to achieve a more reasonable use of these raw materials to obtain energy have been widely investigated at present, especially some studies about the reduction of green house gases.

The hydrogen has a very high combustion heat $\left(\mathrm{HHV}=141.90 \mathrm{~kJ}^{-\mathrm{g}^{-1}}, \mathrm{LHV}=\right.$

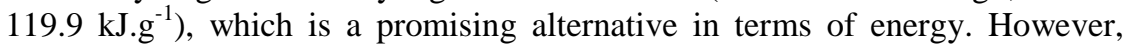
hydrogen must be generated by means of some chemical reaction, because this gas is not encountered available as $" \mathrm{H}_{2}$ " in nature. It is also a very difficult liquefying $\mathrm{H}_{2}$ to be transported or stored ${ }^{(1)}$.

Based upon these considerations, the objective of this work is the production of hydrogen via aluminum-water reaction by applying a catalyst to speed up the rate of gas formation. The presence of the catalyst is necessary because the

\#Corresponding author- E-mail: mmaselim @yahoo. com 
reaction of the metal with water does not occur due to presence of a very thin passivation layer, $\mathrm{Al}_{2} \mathrm{O}_{3}$, which hinders the reaction ${ }^{(2-5)}$. The use of alkalis, like $\mathrm{NaOH}$ and $\mathrm{KOH}$, promotes the complete removal of this layer, so that the reaction with water may proceed ${ }^{(3,4)}$. The reaction that occurs is as follows:

$$
\mathrm{Al}+3 \mathrm{H}_{2} \mathrm{O} \rightarrow \mathrm{Al}(\mathrm{OH})_{3}+\frac{3}{2} \mathrm{H}_{2}
$$

Different mechanisms have been proposed for the reaction presented ${ }^{(5)}$. The formation of an intermediate (pseudoboehmite, $\mathrm{AlOOH}$ ) was considered in a mathematical approach that accounts for the pressure of the hydrogen bubbles formed under the metal surface, thickness of the hydrated oxide film, and other effects. Also, $\mathrm{NaAl}(\mathrm{OH})_{4}$ was considered an intermediate compound, and the replacement of $\mathrm{NaOH}$ by $\mathrm{NaAlO}_{2}$ as catalyst was successfully verified ${ }^{(4,5)}$.

\section{Experimental}

\section{Materials}

Aluminium foil, electrical aluminium wire and beverage aluminium cans were used as aluminium wastes. These materials were crushed or converted into powder. The following chemicals were used : $\mathrm{NaOH}$ (Oxford laboratory), Iodine and $\mathrm{NaCl}$-crystals .

\section{Scanning Electron Microscope}

The Scanning Electron Microscope (SEM) is used for observation of specimen surfaces. When the specimen is irradiated with a fine electron beam (called an electron probe), secondary electrons are emitted from the specimen surface. Topography of the surface can be observed by two-dimensional scanning of the electron probe over the surface and acquisition of an image from the detected secondary electrons.

The specimen must meet the following requirements before it is loaded to the SEM stage: a) The surface to observe is exposed. b) The specimen is firmly fixed to the specimen mount. c) The specimen has conductivity in principle.

\section{Results and Discussion}

The reaction of aluminium with water

Aluminium reacts with water to produce hydrogen gas. The following are possible reactions of aluminium with water.

$$
\begin{aligned}
& 2 \mathrm{Al}+6 \mathrm{H}_{2} \mathrm{O}=2 \mathrm{Al}(\mathrm{OH})_{3}+3 \mathrm{H}_{2} \ldots \\
& 2 \mathrm{Al}=4 \mathrm{H}_{2} \mathrm{O}=2 \mathrm{ALO}(\mathrm{OH})+3 \mathrm{H}_{2} \\
& 2 \mathrm{Al}+3 \mathrm{H}_{2} \mathrm{O}=\mathrm{Al}_{2} \mathrm{O}_{3}=3 \mathrm{H}_{2} \ldots \ldots \ldots
\end{aligned}
$$


These reactions are possible, and from room temperature up to $280^{\circ} \mathrm{C}$ $\mathrm{Al}(\mathrm{OH})_{3}$ is the most stable product ${ }^{(6)}$, while from $289-480^{\circ} \mathrm{C}, \mathrm{AlO}(\mathrm{OH})$ is the most stable ${ }^{(7)}$. Above $480^{\circ} \mathrm{C}, \mathrm{Al}_{2} \mathrm{O}_{3}$ is the most stable product. The above reactions are thermodynamically favorable,

$$
2 / 3 \mathrm{Al}+2 \mathrm{H}_{2} \mathrm{O}=2 / 3 \mathrm{Al}(\mathrm{OH})_{3}+\mathrm{H}_{2} \mathrm{O} .
$$

Reaction of Al with water in the presence of catalyst

When a piece of aluminium was dropped into water no reaction was observed under room temperature conditions and even with boiling water. This is because the aluminium has a thin coherent, adhering layer hydrated of aluminium oxide, $\mathrm{Al}_{2} \mathrm{O}_{3}$ on the surface.

Activation with sodium hydroxide

To prevent the formation of the inert hydrated alumina layer on the Alsurface, sodium hydroxide was used which promotes aluminium-water reaction. The preliminary experiment showed that the vigor of the reaction depends upon the surface of contact between the aluminium and water, aluminium foil reacted faster than a heavy gauge aluminium wire, and aluminium in powdered form reacted instantly to produce hydrogen gas.

All experiments were performed using a Pyrex Erlenmeyer, its capacity was $500 \mathrm{ml}$, containing $200 \mathrm{ml}$ of aqueous solution.

Aluminium foil was cut into little pieces; each piece of aluminium foil was crumpled until forming a small ball, with a weight about 0.05-0.1g.

Effect of temperature and $\mathrm{NaOH}$ contents on the rate of formation of hydrogen

From Table 1, it can be observed that, at concentration $1 \mathrm{M} \mathrm{NaOH}$ the hydrogen production per gram of aluminium increases from $100 \mathrm{~cm}^{3} \mathrm{~min}^{-1}$ at $20^{\circ} \mathrm{C}$ to $200 \mathrm{~cm}^{3} \mathrm{~min}^{-1}$ at $50^{\circ} \mathrm{C}$, while the increase of $\mathrm{NaOH}$ concentration to $5 \mathrm{M}$ increases the hydrogen production from $380 \mathrm{~cm}^{3} \mathrm{~min}^{-1}$ at $50^{\circ} \mathrm{C}$, while the increase of $\mathrm{NaOH}$ concentration to $5 \mathrm{M}$ increases the hydrogen production form $380 \mathrm{~cm}^{3} \mathrm{~min}^{-1}$ at $20^{\circ} \mathrm{C}$ to $1500 \mathrm{~cm}^{3} \mathrm{~min}^{-1}$ at $50^{\circ} \mathrm{C}$, and at $80^{\circ} \mathrm{C}$ hydrogen production was $300 \mathrm{~cm}^{3} \mathrm{~min}^{-1}$ when sodium hydroxide was $1 \mathrm{M}$ and $3500 \mathrm{~cm}^{3}$ $\min ^{-1}$ when sodium hydroxide was $5 \mathrm{M}$.

TABLE 1. Effect of temperature and $\mathrm{NaOH}$ contents on the rate of formation of hydrogen.

\begin{tabular}{|c|c|c|c|c|c|c|c|}
\hline $\mathbf{M ~ N a O H}$ & $\mathbf{2 0}^{\circ} \mathbf{C}$ & $\mathbf{3 0}^{\circ} \mathbf{C}$ & $\mathbf{4 0}^{\circ} \mathbf{C}$ & $\mathbf{5 0}^{\circ} \mathbf{C}$ & $\mathbf{6 0}^{\circ} \mathbf{C}$ & $\mathbf{7 0}^{\circ} \mathbf{C}$ & $\mathbf{8 0}^{\circ} \mathbf{C}$ \\
\hline 1 & 100 & 133 & 167 & 200 & 233 & 297 & 300 \\
\hline 5 & 380 & 840 & 1250 & 1500 & 2050 & 3450 & 3500 \\
\hline
\end{tabular}




\section{Activation with iodine}

It is known that $\mathrm{Al}$ can react with $\mathrm{I}_{2}$ in ethanol at room temperature forming $\mathrm{AlI}_{3}{ }^{(8)}$. This means that $\mathrm{I}_{2}$ can penetrate through the surface oxide layer formed on $\mathrm{Al}$ and reacts with $\mathrm{Al}$ powder to form $\mathrm{AlI}_{3}$. Consequently the surface d oxide layer could be destroyed and the inert $\mathrm{Al}$ powder is activated for further chemical reaction.

The reaction was conducted by adding $0.5 \mathrm{~g}$ iodine to $100 \mathrm{ml}$ water and heating the mixture at constant temperature $80^{\circ} \mathrm{C}$. The hydrogen production reaction started when $\mathrm{Al}$ powder was added to the heated $\mathrm{I}_{2}$ aqueous solution.

To understand the mechanism of the reaction, the possible chemical reactions with $\mathrm{I}_{2}$ can be written as:

$$
\begin{aligned}
& 2 \mathrm{Al}+3 \mathrm{I}_{2} \rightarrow 2 \mathrm{AlI}_{3} \\
& 2 \mathrm{AlI}_{3}+6 \mathrm{H}_{2} \mathrm{O} \rightarrow 6 \mathrm{HI}+2 \mathrm{Al}(\mathrm{OH})_{3} \\
& 2 \mathrm{Al}+2 \mathrm{HI} \rightarrow 2 \mathrm{AlI}_{3}+3 \mathrm{H}_{2}
\end{aligned}
$$

The reaction between iodine and aluminium leads to the formation of $\mathrm{AlI}_{3}$. This reaction leads to the removal of surface oxide layer and reactivates the aluminium powder.

Based on the above results, the formation of $\mathrm{AlI}_{3}$ plays an important role on activating aluminium for producing hydrogen.

Table 2 shows the dependence of hydrogen production on temperature. From Table 2 it is clear that the increase of reaction temperature increases the rate of hydrogen production.

TABLE 2. The dependence of hydrogen production on temperature.

\begin{tabular}{|c|c|c|}
\hline Temperature $^{\mathbf{0}} \mathbf{C}$ & After $\mathbf{5 h r}, \mathbf{m l}$ & After $\mathbf{1 0 h r}, \mathbf{m l}$ \\
\hline 50 & 190 & 260 \\
\hline 60 & 245 & 320 \\
\hline 70 & 285 & 390 \\
\hline
\end{tabular}

The examination by SEM of the aluminium powder surface before and after treatment with iodine (Fig. 1 and 2) showed the formation of holes on the surface of aluminium flakes. This is due to the interaction of iodine with aluminum. This means that the formation of $\mathrm{AlI}_{3}$ allowed for the attack of the aluminium surface by water thus forming these holes with the production of hydrogen. 


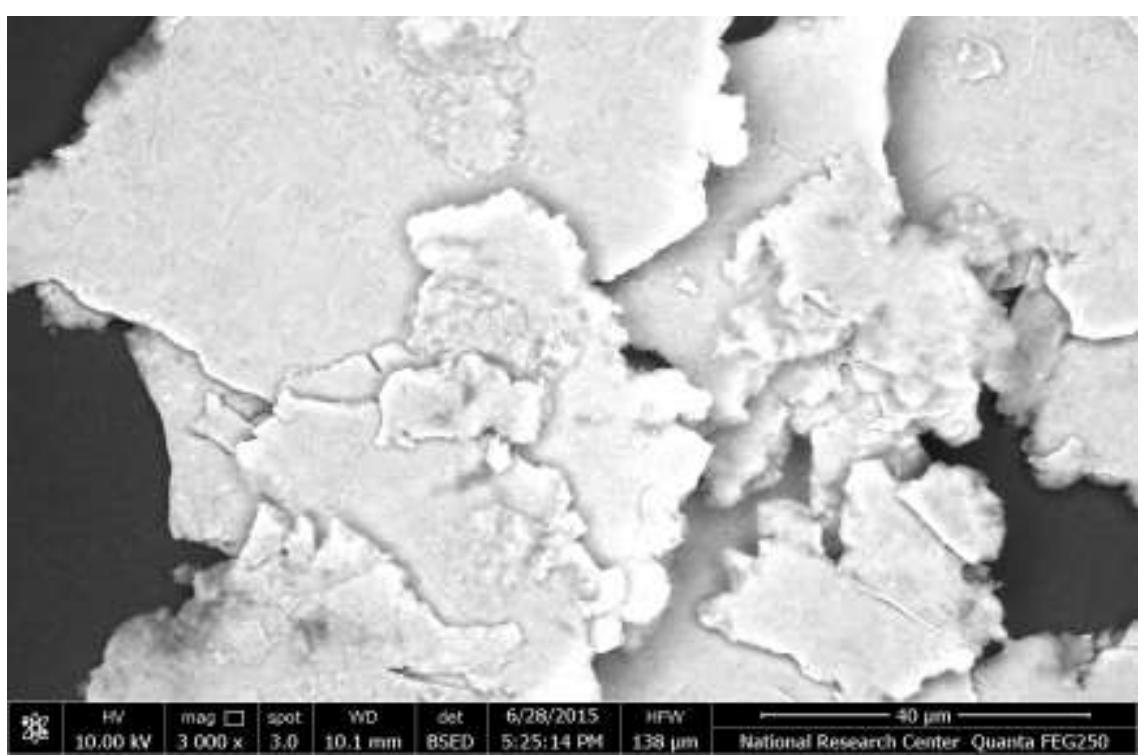

Fig. 1. SEM image of aluminium powder .

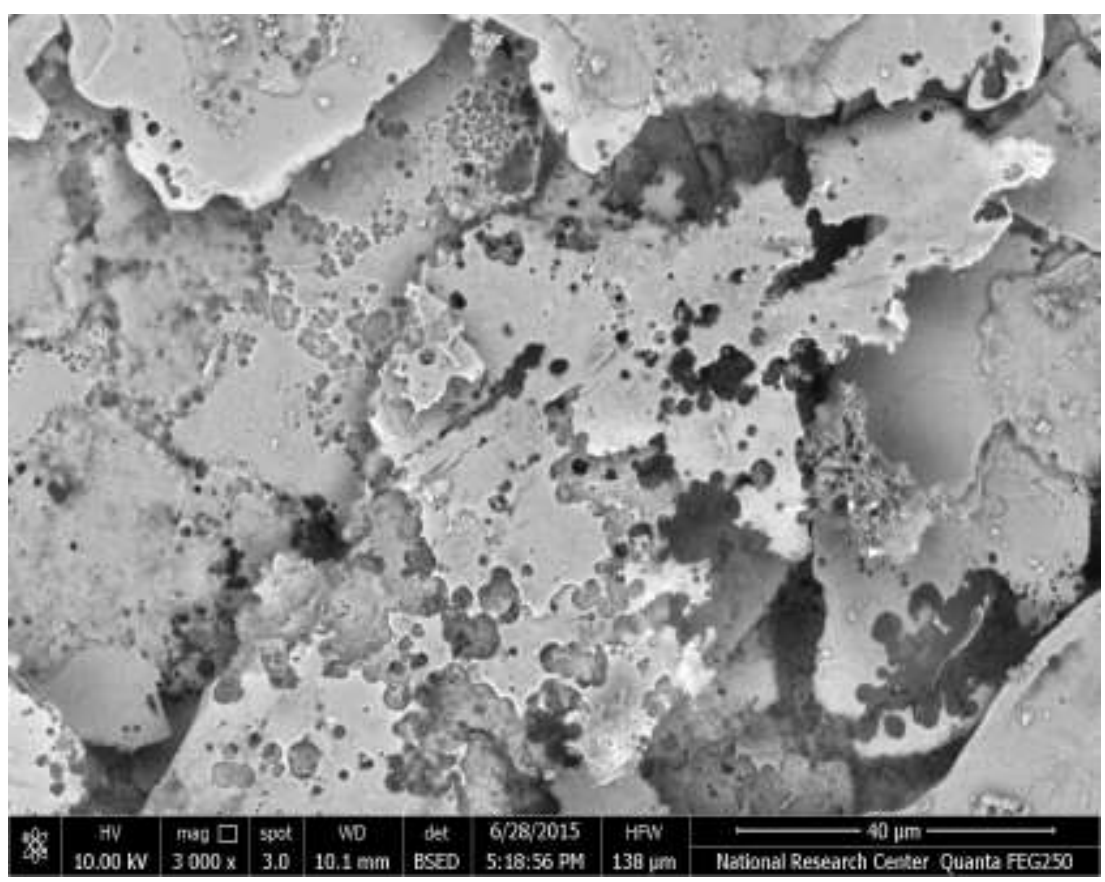

Fig. 2. SEM image of aluminium powder after treatment with $\mathbf{I}_{2}$. 
Activation by milling with sodium chloride salt

In this activation method, aluminium is milled using salt particle . Due to their brittle nature, salt particles are fractured during milling and their sharp edges chop aluminium particles into pieces. This leads to an increment in hydrolysis kinetics. Meantime, salt particles are driven into newly created surfaces of aluminium particles, producing salt gate that will be removed in water environment, causing hydrogen generation reaction to proceed.

To confirm the effect of sodium chloride on aluminium flakes, these flakes were examined by SEM. The SEM image is given in Fig . 3. shows that the aluminium particles were chopped into pieces allowing thus the reaction of aluminium with water to produce hydrogen.

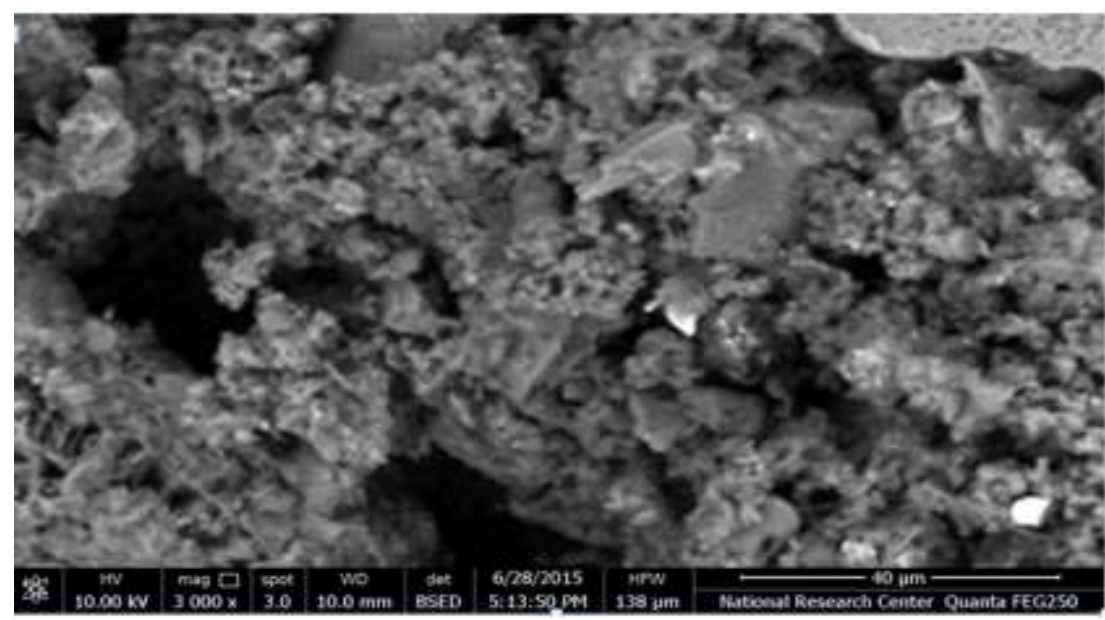

Fig. 3. SEM image of aluminium powder after treatment with $\mathrm{NaCl}$.

\section{Conclusions}

From the previous results presented in this work it is possible to conclude that the aluminum corrosion is strongly influenced by temperature and activator concentration. Moreover, the speed of aluminum consumption is faster at higher concentrations of alkali. $\mathrm{NaOH}$ is the most active catalyst among the used activator materials.

\section{References}

1. Tzimas, E., Filiou, C., Peteves, S.D. and Veyret, J.B., Hydrogen Storage: State-ofthe-Art and Future Perspective European Commission - Joint Research Centre (2003).

2. Wang, H.Z., Leung, D.Y.C., Leung, M.K. H. and Ni, M., A review on hydrogen production using aluminium and aluminium alloys. Renewable \& Sustainable Energy Reviews, 13, 845-853 (2009).

Egypt. J. Chem. 58, No. 5(2015) 
3. Soler, L., Candela, A.M., Macanás, J., Muñoz, M. and Casado, J., In situ generation of hydrogen from water by aluminum corrosion in solutions of sodium aluminate. Journal of Power Sources, 192, 21-26 (2009).

4. Soler, L., Macanás, J., Muñoz, M. and Casado, J., Aluminum and aluminum alloys as sources of hydrogen for fuel cell applications. Journal of Power Sources. 169, 144-149 (2007).

5. Grosjean, M.H., Zidoune, M. and Roué, L., Hydrogen production from highly corroding Mg-based materials elaborated by ball milling. Journal of Alloys and Compounds, 404-406, 712 - 715 (2005).

6. Deng , Z. and Ferreira, J.M.F., Physicochemical mechanism for the continuous reaction of $\gamma-\mathrm{al}_{2} \mathrm{O}_{3}$-modified aluminum powder with water. Journal of American Ceramic Society, 90, 1521-1526 (2007).

7. Digne, M., Sautet, P., Raybaud, P., Toulhoat, H. and Artacho, E., Structure and stability of aluminum hydroxides: A theoretical study. J. Phys. Chem. B 106, 5155$5162(2002)$.

8. Xue, B.F., Fu, Z.W., Li, H., Liu, X.Z., Cheng, S.C., Yao, J., Li, D.M., Chen, L.Q. and Meng Q.B., Cheap and environmentally benign electrochemical energy storage and conversion devices based on $\mathrm{AlI}_{3}$ electrolytes. J. Am. Chem. Soc. 128 (27), 8720 (2006).

\section{انتاج الهيدروجين من مخلفات صناعية معدنية}

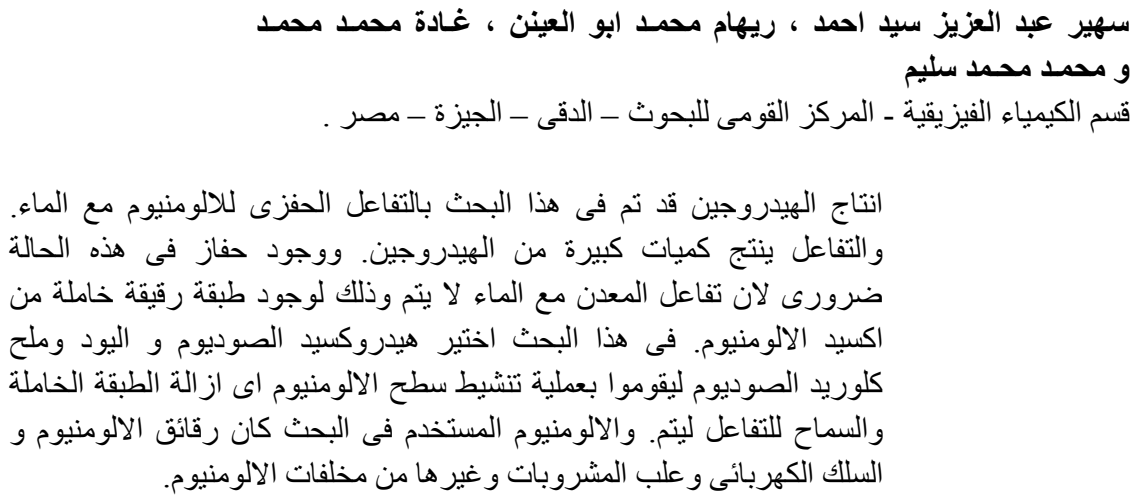


